\title{
Artistic
}

\section{TRANSFORMATION OF TENGKULUK TANDUK WITH WEAVING TECHNIQUES}

\author{
Lidia Purnama Sari ${ }^{1}$, Ahmad Akmal ${ }^{2}$, and Dharsono ${ }^{3}$ \\ ${ }^{1}$ Institut Seni Indonesia (ISI) Padangpanjang, Indonesia \\ ${ }^{2}$ Institut Seni Budaya Indonesia (ISBI) Aceh, Indonesia \\ ${ }^{3}$ Institut Seni Indonesia (ISI) Surakarta, Indonesia \\ E-mail correspondence: lidiapurnamasari3@gmail.com
}

\begin{abstract}
Tengkuluk is one of the traditional clothing equipment (head cover) of a Bundo Kanduang (biological mother) in the Minangkabau tribe. Currently tengkuluk is rarely used in everyday life, only used in traditional events or other official activities. This reality encourages the creation of this tengkuluk work to be carried out. The method of creating works used consists of three stages, namely experimentation, reflection, and formation. The result of the creation of this work shows that the tengkuluk made with woven techniques and pandan leaf material and decorated with Swarovski looks practical and flexible when used by mothers and teenagers in their daily lives. This new creation in the form of the Koto Gadang tengkuluk expresses the meaning of philosophical values, namely the responsibility of women when they have married.
\end{abstract}

Keywords: Tengkuluk, Minangkabau, weaving, and transformation.

\begin{abstract}
ABSTRAK
Tengkuluk merupakan salah satu perlengkapan pakaian tradisional (penutup kepala) seorang Bundo Kanduang dalam suku Minangkabau. Saat ini tengkuluk jarang digunakan dalam kehidupan sehari-hari, hanya dipakai dalam acara adat atau kegiatan resmi lainnya. Realitas itu mendorong penciptaaan karya tengkuluk ini dilakukan. Metode penciptaan karya yang digunakan terdiri atas tiga tahap yaitu eksperimen, perenungan, dan pembentukan. Hasil penciptaan karya ini menunjukkan bahwa tengkuluk yang diciptakan dengan teknik anyaman dan bahan daun pandan serta dihiasi Swarovski tampak praktis dan fleksibel jika digunakan para ibu dan remaja dalam keseharian mereka. Kreasi baru berupa tengkuluk Koto Gadang ini mengungkapkan makna nilai filosofis yaitu tanggung jawab perempuan ketika sudah menikah.
\end{abstract}

Kata kunci: Tengkuluk, Minangkabau, anyaman, dan transformasi

\section{Introduction}

Tengkuluk is one of the complementary clothing in the form of a headdress worn by Minangkabau women. Minangkabau women who use this tikuluak are 
called Bundo Kanduang. How to use Tengkuluk is just paired on top of the head. Tengkuluk horn is one of the completeness of traditional traditional clothing in Minangkabau, namely a head covering worn by Minang women in the form of a horn-shaped skullcap. Its horn-like shape is often philosophized as a form of buffalo horn which is a very iconic part of tribe Minangkabau. In addition, its shape is also often analogous to the gonjong shape of Rumah Gadang which is a typical Minangkabau traditional house.

Tengkuluk horns are usually made of thick woven songket cloth and are given a gold or red color which is one of the typical colors of Minangkabau traditional clothes. On the back of the tengkuluak, the horn is usually decorated with a cloth that falls backwards. Muhammad Jamil explained, "Tengkuluk is the head covering of a woman who has been appointed as a bundo kanduang. A head covering that is worn in a certain way, so that its shape resembles a buffalo horn which has two pointed horns or gonjong the shape of the roof of a Minangkabau house" (Jamil, 2015).

The shape of the Tengkuluk Minangkabau is very diverse according to their respective regions which are made of balapak cloth, sarong, and long cloth according to the type of use. The shape resembles a buffalo horn which means a bundo kanduang must be balanced between left and right. The use of this tengkuluk is of two types, namely the tengkuluk of cloth balapak used in traditional events or baralek (party) events, while the tengkuluk of sarong cloth is used by bundo kanduang in her daily life.

Tengkuluk can be distinguished from the way it is used, the shape, and the cloth used. In Agam Regency, there is a tengkuluk that resembles a horn with two sides that are sharp like buffalo horns, with the ends of the cloth dangling forward and decorated with brass tassels. This type is made using balapak cloth and is usually used by girls in traditional dances and bridesmaids at weddings. Another variety of tengkuluk is circular in shape with the ends of the cloth dangling from the top towards the back or commonly known as tengkuluk Bundo Kanduang. This tengkuluk is also made of balapak cloth, and is usually only worn by adult women 


\section{Artistic}

and is worn on traditional official events. The other type of tengkuluk is in the form of a scarf attached to the head and decorated with gold thread embroidery, and is well known as the tengkuluk Koto Gadang. This type of tengkuluk is used at weddings by the bride, and it is made of velvet.

Tengkuluk symbolizes Rumah Gadang (big house) or Minangkabau traditional house. The community assumes that the traditional house belongs to women or mothers, in accordance with the matrilineal lineage adopted by the Minangkabau ethnic.

The development of technology at this time causes many people, especially the young generation, who do not understand or know in depth about the tengkuluk. Everything related to the tengkuluk is only known by people who are old. Because of the importance of the tengkuluk for the Minangkabau community, especially for the Agam Regency area, it is necessary to develop further designs in order to preserve cultural heritage, especially the tengkuluk.

Currently, the tengkuluk has developed into various forms due to the influence of outside cultures. However, each region has a different way of using it, especially the Minangkabau area. The Minangkabau people have developed their own culture based on Islam.

The description above illustrates that the customs used by the Minangkabau people are customs that are in line with the teachings of Islam. In ancient times, the tengkuluk was worn on the heads of Minangkabau women by showing the neck. Meanwhile, now women have covered their necks by using the hijab before placing the tengkuluk on their heads. However, now many Minangkabau people forget the tengkuluk and only wear it during traditional events and are considered as parents' clothes, even teenage girls are reluctant to wear it.

On the basis of the above reality, the creation of this artwork was carried out. The author tries to transform the tengkuluk into a medium for expressing personal expressions based on the meaning of the tengkuluk for Minangkabau women according to the philosophy of Bundo Kanduang. The works of art that are created 
are not just making the tengkuluk, but also how the meaning of the tengkuluk has been created.

The creation of works cannot be separated from the touch of Minangkabau tradition in terms of techniques, colors, and motifs used. From the explanation above, there is an interest in developing the shape of the tengkuluk using woven techniques that are not only used in traditional events, but can also be used for fashion at parties and for everyday life.

The creation of this work of art is intended so that it can be used by young people for daily activities, so that the tengkuluk will still exist and be sustainable where it will continue to be used from generation to generation. In addition, this creation aims to preserve the tengkuluk by renewing both materials and different motifs.

\section{Literature Review}

Concepts and forms in a work of art form a style and then become a special character for the creator starting from an aesthetic experience. Aesthetic experiences are inspired by phenomena in everyday life. Furthermore, from this aesthetic experience brings and provokes the birth of a source of ideas for the creation of an artwork.

The theory used to underlie the creation of this work, first is Form. Clive Bell who stated "The essence of art is an important form (significant form)" (Gie, 1996). Form is an object feature that appears on an object. Form is basically the totality of the work of art. Form is an organization or a unit or composition of the supporting elements of the work. There are two kinds of forms, namely Visual Form, which is the physical form of a work, and Special Form, which is a form created because of the reciprocity between the values emitted by the phenomenon of its physical form and responses to emotional awareness (Kartika, 2017). Form is occurs as a result of a combination of several spaces. Basically form is the physical appearance or overall 


\section{Artistic}

form of a work of art. From this form it can be seen what is the essence of a created work.

The second theory is Function. The function of art in general is as a form or way of conveying one's expression to other people and their environment. Art works for the individual as well as for the social. Nasbahri Couto states that the convention in making works of art is that it is separated from the element of useful, while the convention of making disposable objects is useful, making used objects requires awareness of their usefulness (Couto, 2008). That is why, in design and education of design, aspects of the goals, procedures, and planning processes are very important.

In addition to form and function, the color aspect is also considered. Color is one of the elements of art that is very important, even color plays a very important role in human life, not only used to create or decorate a work of art, but also objects and equipment used by humans, from clothing, jewelry, to household appliances. Color as a representation of nature, color as a symbol or sign, and color as a symbol of expression (Kartika, 2004).

In addition, aesthetic theory is also the basis for the creation of this work. Aesthetics is the beauty of an artwork. Artwork will look good if it contains unity, complexity, and sincerity, so that the artwork will be able to have a dialogue with the audience. Jacob Sumardjo explained that aesthetics is a form that has a difference with philosophy, the difference lies in the comprehension between aesthetics and the philosophy of art, namely the object being assessed. Nasral Yuzaili also explains aesthetics as a philosophy contextually discusses what beauty is, how beauty occurs and what beauty is for (Yuzaili, 2018). From some of the opinions above, it shows that aesthetics is knowledge that discusses a beauty or a process of combining patterns, the parts that will later arise into a work that can be enjoyed by the public for its beauty.

\section{Creation Methodology}

The method is a working technique or process of creating works in accordance with the data sources under study. In this regard, M. Hamzah (2018) explains that 
"The presence of a work of art certainly goes through a process of creation that has been thoroughly thought, both concerning ideas, forms, materials, technical, meaning, which want to be conveyed through the created works of art" (Hamzah, 2018).

This method of creation is used to create works of art according to the concept of creation. The following method is used in the process of creating this work of art.

1) Experiment

Dharsono Sony Kartika defines experimentation as an activity step carried out by an artist or designer in the creation process, which includes: (1) trying several alternative materials that are suitable and proper for the expression of the designed art creation, (2) trying several alternative individual techniques that match to the expression in the designed artistic creation, (3) trying several alternative tools that match to the expression in the designed artistic creation, and (4) the selection of visual concepts (layout) (Kartika, 2016).

Experiments in this study were carried out by trying to find techniques for making tengkuluk and also adjusting materials. In carrying out this experiment, the author uses a weaving technique and uses pandan material. After experimenting with materials and techniques, better and more precise results can be determined. The shape of the tengkuluk using pandan material is considered the best, because the pandan material is lighter (not heavy), easy to shape, and easy to weave and it is faster to work. Meanwhile, the cloth material is used only as an addition to the sequin element which is usually difficult to create in forming the tengkuluk.

\section{2) Contemplation}

Contemplation is the inner depiction of the artist in search of symbols (metaphors). Contemplation is carried out to seek and find symbols that will become icons in the artistic creative process in the creation of works of art (Kartika, 2016). Contemplation is needed by artists when looking for ideas for works of art to be created. 


\section{Artistic}

Contemplation in the process of creating this work is used to find the main motive and find the character to be created. This is done by observing the Minangkabau traditional art forms and the philosophical meanings of Bundo Kanduang contained in the traditional tengkuluk. The hope is that the tengkuluk creations that are created will show the uniqueness and locality of Agam Regency.

3) Formation

Formation is a layout design or composition designed to get the form or structure of the work (Kartika, 2016). The structure of a work of art is a composition that will always be related to the quality of the elements, the principles of layout, and the principles of layout. The design of this tengkuluk work uses the concept of expression by combining modern techniques with a touch of tradition. The formation of tengkuluk works to bring out new forms as a result of creations and innovations that are in accordance with current needs.

To strengthen the idea of creation, several rationale and theory are used to create the desired shape or form, and can also understand the work created, such as the opinion of Constable referred by Herbert Read in his book The Meaning of Art, states "We won't see things properly if we don't understand" (Read, 1959). To understand about craft one must study diligently, as well as the concept of the work that will be created by the artist, the artist must understand how the form and the meaning of the concept are.

\section{Discussion}

\subsection{Developing Concept}

This work is designed in such a way for the comfort of the user. Meanwhile, the segmentation of potential users is teenagers. The creation of this work is in the form of a tengkuluk using a weaving technique made from pandan leaves. The weaving technique is used for the purpose of adding to the aesthetic value of the tengkuluk to make it attractive. The ease of techniques and materials will have an impact on anyone who wants to apply them in craft production. In addition, there are 3 elements that are applied in the design of this tengkuluk, namely unity, complexity, 
and seriousness.

The forms of the tengkuluk in Minangkabau culture are usually in the form of pointed and large buffalo horns, but in this creation the tengkuluk is modified and styled to be different from the traditional tengkuluk. This is so that it is easy to use and in accordance with the tastes of the times that are all practical and minimalist. The function of the work created is not only for use during traditional events, but it can be used for everyday use by mothers and young women. Tengkuluk designed as a work of art is expected to meet the value of usability or functional objects. The physical function of the designed tengkuluk is as a head covering during traditional and daily events. The personal function of this work is creativity and artistic expression expressed by its creator, while its social function is as a means of conveying meaning or messages to the audience. In addition to the aspect of form and function, the tengkuluk has a symbolic value, which symbolizes a woman who is brave and responsible.

Based on the explanation of the concept above, it can be concluded that the creation of the tengkuluk works using a weaving technique with pandan leaf material which has a function as a head covering. The beauty of the tengkuluk is shown in terms of the color and shape of the motifs that adorn it. The colors applied are the typical colors of the Minangkabau region, namely red, yellow, black, purple, green, and blue. An artwork is not only to fulfill practical needs, but has an aesthetic value so that it can be more attractive.

\subsection{Artwork Description}

The work entitled "Tengkuluk Gadih Koto Gadang" is a work made of woven material, namely pandan leaves in cream, green and red colors, while the furing uses cream colored toyobo cloth. The tengkuluk decoration uses white round shell Swarovski stones. The red color symbolizes courage, strength and energy, the green color symbolizes coolness and the cream color symbolizes tenderness.

The shape of the tengkuluk works using a cita motif combined with Swarovski 


\section{Artistic}

which is attached to the entire tengkuluk in green and red colors. The use of this tengkuluk is only attached directly to the top of the woman's head easily and practically, does not require complicated special treatment.

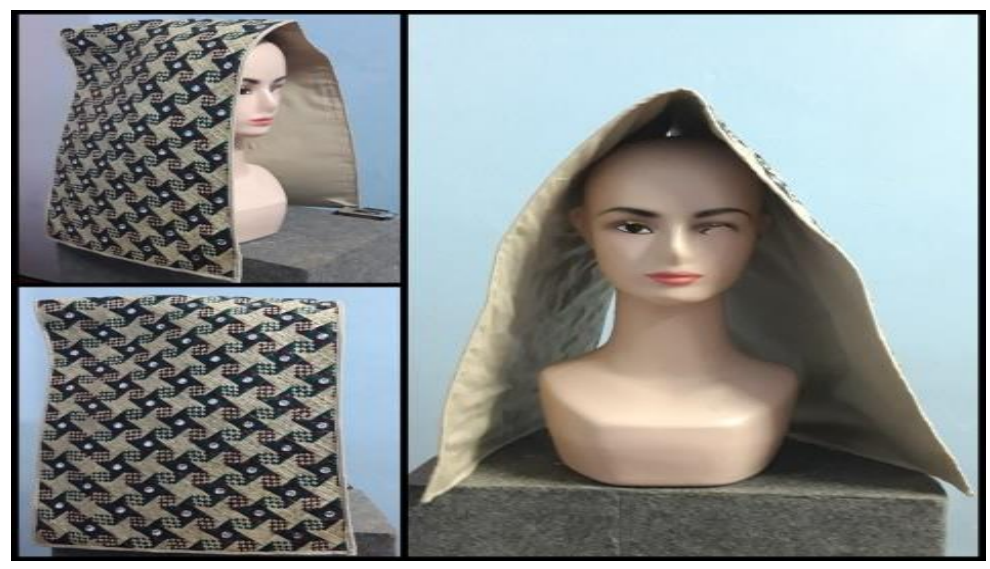

Figure 1. "Tengkuluk Gadih Koto Gadang"

(Designer: Lidia, 2020)

\subsection{Interpretation}

The shape of the tengkuluk of the Koto Gadang can also be used by brides at weddings. This Tengkuluk symbolizes or expresses the meaning of philosophical values, namely the responsibility of women when they have married. Married women are required to obey their husband, maintain self-respect, educate their children, maintain household harmony, carry out religious teachings, maintain good speech or behavior to their husband and learn to do good in all things.

\section{Conclusion}

Tengkuluk horn is one of the traditional clothing equipment (head cover) of a Bundo Kanduang in Minangkabau tribe culture in Sumatra, Indonesia. Currently, the tengkuluk tanduk is rarely used in the daily life of Minang women. Tengkuluk tanduk are only used in Minangkabau traditional events or other official activities. The tengkuluk phenomenon inspired the creation of this work of art.

This new Tengkuluk creation was created using a weaving technique and pandan leaf material. The woven pandanus leaf is decorated with pearls or 
Swarovski. The shape of the tengkuluk is no longer horn-shaped, and the colors used are cream, red, green and purple. Tengkuluk Koto Gadang symbolizes or expresses the meaning of philosophical values, namely the responsibility of women when they have married. By making this work, it is hoped that the tengkuluk can be used again by mothers and young people in their daily activities.

\section{References}

Couto, N. (2008). Budaya Visual Seni Tradisi Minangkabau. Padang: UNP Press.

Gie, T. L. (1996). Filsafat Seni. Yogyakarta: PUBIB.

Hamzah, M. (2018). Transformasi Ornamen Rumoh Aceh Teungku Chik Awe Geutah pada Rapa'I Aceh. Melayu Art and Performance Journal, 1(2).

Jamil, M. (2015). Padusi Minang Mencari Identitas Bundo Kanduang dalam Konteks Islam. Bukitinggi: Cinta Buku Agency.

Kartika, D. S. (2004). Seni Rupa Modern. Bandung: Rekayasa Sains.

Kartika, D. S. (2016). Kreasi Artistik: Perjumpaan Tradisi Modern dalam Paradigma Kekaryaan Seni. Karanganyar: Citra Sains LPKBN.

Kartika, D. S. (2017). Seni Rupa Modern. Bandung: Rekayasa Sains.

Read, H. (1959). The Meaning of Art. Penguin Books.

Yuzaili, N. (2018). Hiasan dan Kaligrafi Makam Shadrul Akabir Abdullah di Kabupaten Aceh Utara. Melayu Art and Performance Journal, 1(2).

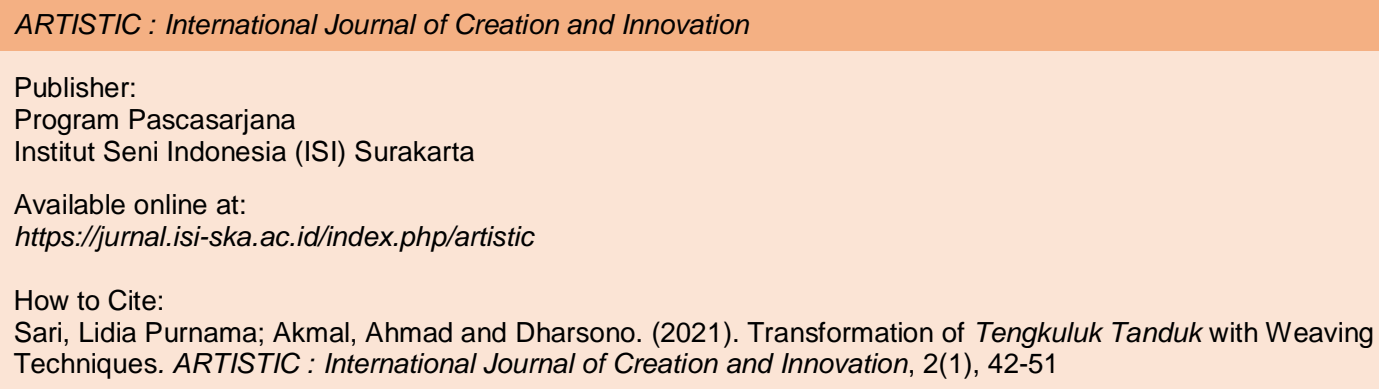

